\title{
Acceptance: on 1956: desire and the unknowable
}

\section{Sue Hajdú}

People robbed of their past seem to make the most fervent picture takers, at home and abroad.

Susan Sontag , On Photography

On the afternoon of October 23 1956, the first day of the Hungarian uprising, my father (Hajdú László) was one of the thousands of students, intellectuals and workers who gathered in Budapest to demonstrate for political reform. They rallied for Imre Nagy, their chosen political leader, but when he failed to deliver the desired speech, the crowd eventually dispersed. The fateful shooting that triggered the ensuing violence had already occurred outside the radio building. My father chose neither to go to the radio, nor to the Stalin statue, which was then being pulled down. Instead, he joined a group of youths anxious to have the students' demands printed. He spent the night with these strangers in a basement printery.

The printers discovered all sorts of 'technical problems' that prevented them from printing up the demands. At dawn, my father left Buda, crossed the Danube and arrived at his room in downtown Pest. His immediate instinct was to reach for his camera. He went out on to Andrassy Avenue and took his first photograph—a Soviet armoured personnel carrier running along the street; in the background one of the city's oldest pharmacies and a few people huddled in a doorway.

For the next eleven days he wandered the streets of Budapest, his camera hidden behind his overcoat or under the sandwiches in his satchel. Officially, the uprising continued until November 4, when several thousand Soviet tanks crossed the borders into Hungary. 
Stationed on almost every street corner, they shot at the first sign of human movement. This effectively put an end to my father's picture taking. In all, he had made 145 exposures. He took the films with him on his escape to Austria in December 1956, where they were subsequently developed and printed. ${ }^{1}$

I discovered these prints during my teens and would look at them from time to time. In these first experiences, what had stirred me most was the presence of death. Many of the photographs are images of bodies - the Soviet soldiers, Hungarian citizens and secret police (Allamvedélmi Osztály: AVO) who died during those weeks. They lie on the streets covered in lime, flowers and flags, or rubbish, depending on their role in events. On the edges of the frame are the feet of Budapest's citizens, looking [see figure 1].

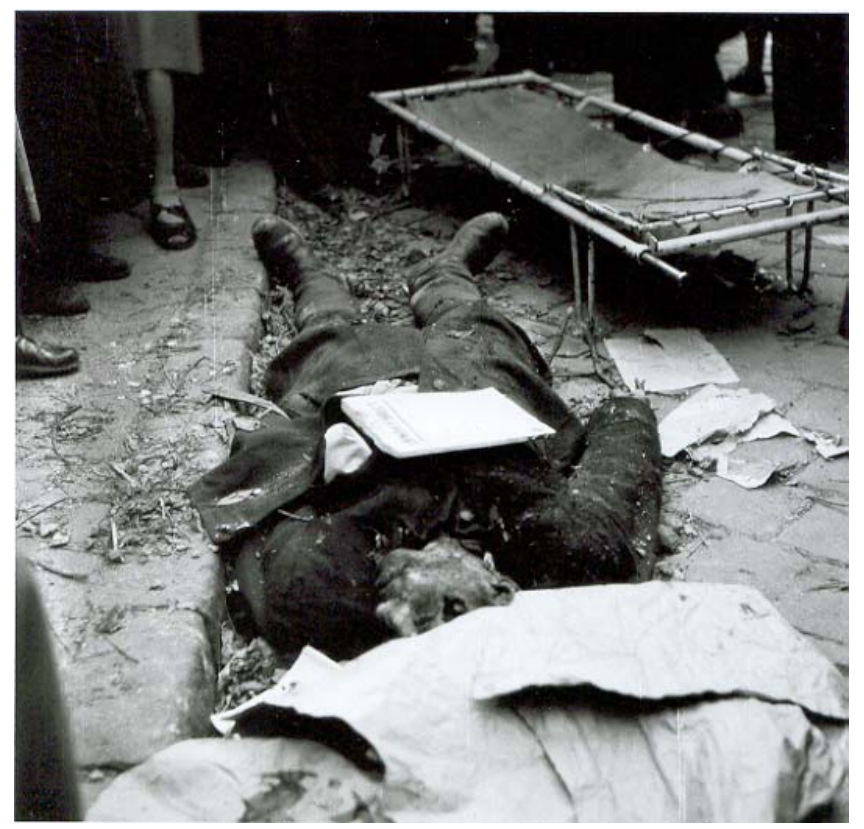

Figure 1: Photograph of dead AVO, by Hajdú László, Budapest, 1956.

My parents were not the type to tell stories or reminisce about the past. They never explained these pictures, so I was unsure of the exact significance of such details. I knew that the photographs depicted the uprising — the 'revolution,' as the Hungarian émigrés called it—but I could not identify anything beyond 'October 1956.' Yet I recognised in

\footnotetext{
${ }^{1}$ He and my mother met some months later in one of the refugee camps in Austria.
} 
that date a tumultuous event that my parents had experienced and that had brought both of them to the edge of death. This was enough to make me cry over these pictures on several occasions. The experience resonates strongly with Susan Sontag's well-known encounter with photographs of Bergen-Belsen and Dachau (1977).

My emotions were also aroused by a vague sense of myself as Hungarian. The photographs represented a past (event) that cut me off from my past (ancestry). I recognised parts of myself in those photographs.

I can liken my feelings to those of Anne McDonald when viewing a photograph that her father had shot when they were tourists in New Guinea: 'I find I am secretly hoping it will reveal a memory; I become immediately enthralled by evidence of my past ... Urgent with longing, I accuse the image for not facilitating a return to that...memory' (1988, 61). The photograph reduces McDonald to fundamental questions: 'Who was my father when he took that photo?' and 'Why am I here now?' (1988, 61). For me, this feeling is particularly intense in my father's 1956 photographs.

As a child of Hungarian refugees who immigrated to Australia — as a member of the diasporas that typify the $20^{\text {th }}$ century - I feel that in many ways my past is a foreign country. This only became evident to me when I returned to Hungary in 1990 and again in 2000. Place is important here, but so too is story. The parts of Hungary that vibrate strongly with spirit of place are those that my father or my relatives tell stories about. Becoming aware of the generational chain back across time makes me feel I do indeed have a long and compelling past. Meanwhile in Australia I feel rootless. We have no past there beyond the year of my parent's arrival: 1958.

As the diasporic returnee, I underwent a process of re-sensitization to past and to place, by listening to stories and working with old photographs. Albeit in a different context, this process in beautifully expressed by Ross Gibson in the catalogue essay of Crime Scene, an exhibition of forensic photography held in Sydney in 1999: 
You begin to feel a deep emotional charge running through your city.... You sense that every street corner, every vacant lot, back-alley and culvert in this city is energised by past humanity. Call it history, call it spirit of place-whatever name you give it, it starts to follow you everywhere you go. (1999)

But the past is gone, and no photograph can retrieve it. What Gibson gained from viewing photographs was not the past as it was, for that is impossible. What he gained was a sense of the past; or more precisely, his sense of the past.

Even without privy knowledge I recognise my father as an amateur in his photographs. Perhaps the biggest clue is the safe distance of his framing. ${ }^{2}$ He had no professional reasons for risking his life to get a close shot. Generally he frames the entire scene, often including a wide expanse of road in the foreground. In other pictures his photographic skills betray him—sometimes the centre of interest is obscure, or the photographs are blurry, or poorly exposed [see figures 2 \& 3].

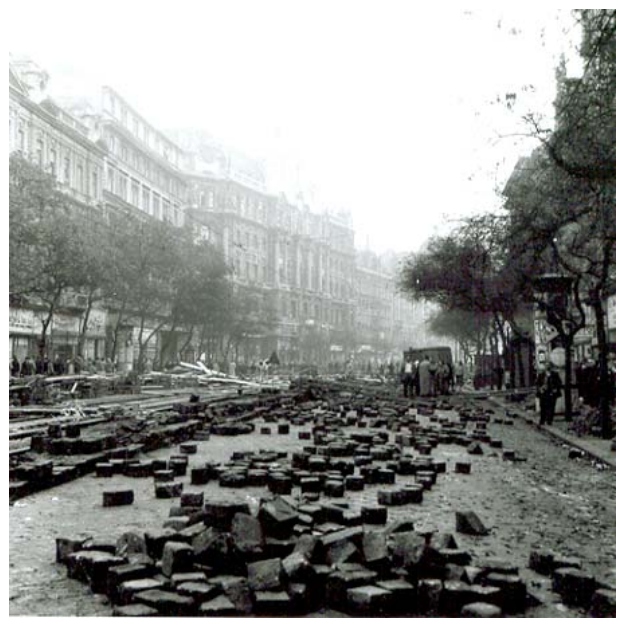

Figure 2: Photograph of the Grand Ring Road, by Hajdú László, Budapest 1956.

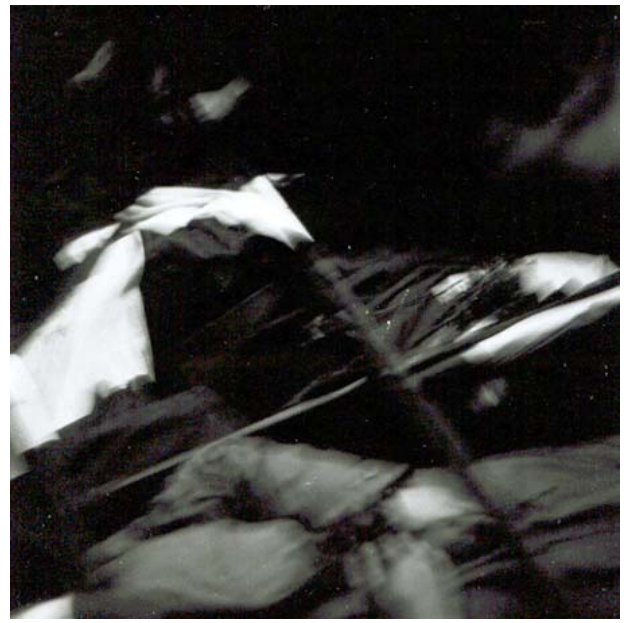

Figure 3: Photograph of the dead with national flags, by Hajdú László, Budapest, 1956.

Photographs taken by professional photojournalists play a large part in creating and maintaining memories of historical events. Underwritten by the authority of the media,

\footnotetext{
${ }^{2}$ There were political reasons for his safe framing as well. He was aware that if the films were to be found by the AVO, the people in the pictures could be identified. Thus, he maintained a distance and also usually asked those in the foreground of the shot to turn around. His fears were realistic - in the aftermath of the uprising, many people were executed or imprisoned after being identified from photographs.
} 
such images make a strong claim to truth. In the discourses of war photography, we rarely consider images by the unknown, fumbling amateur-the local citizen-for whom possibly much more than his own physical safety is at stake.

But vernacular photographs can tell very different stories. There is something more adhoc, more subtle, in the way amateur photographs depict historical events. My father does not organise his pictures in the manner of the professional photographer, but I see the value of his work precisely in the way that it bypasses such technical and conceptual skills. As a result, his photographs pick up details that would have been deemed either too un-noteworthy or too unpalatable to be put into public circulation. This allows a more complex message about the nature of war to slip through.

In the following discussion, I will focus on three of my father's recurring motifs, all of which work to subvert the standard etiquette of war photography. These are the dead body, the gazing crowd, and (the non-motif of) non-heroism.

I have encountered multiple forms of representation of 1956 —stage plays that were put on by the Hungarian community in Melbourne, photographs, posters, collections of photography such as Cry Hungary (Gadney 1986). Repeatedly, the message is that the revolution was heroic and tragic. Growing up in Melbourne, I had always felt instinctively ambivalent about all these depictions of the Hungarian heroes. Surely those Hungarian émigrés that formed my parents’ social circle could not have all been heroes.

The urge to represent heroism can sometimes be so strong as to over-ride the 'truth' of photo-journalism. In a provocative analysis of Robert Capa's Death of a Republican Soldier, Caroline Brothers (1997) argues that this photograph, rather than capturing the soldier at the moment he fell, was in fact a fake. ${ }^{3}$ She concludes that 'the fame of this photograph is indicative of a collective imagination which wanted and still wants to believe certain things about the nature of death in war ... What this image argued was that

\footnotetext{
${ }^{3}$ My father encountered a similar situation in Budapest, when he witnessed Jean-Pierre Pedrazzini, shooting for Paris-Match, staging a shot of one of the 'freedom fighters' firing a rifle into the distance. Looking at this photograph with the critical eye that I have gained, I have no doubt that it was staged.
} 
death in war was heroic, and tragic, and that the individual counted and that his death mattered' $(1997,183)$. This is what most of us, including the Hungarians, would like to believe about death in war.

My father’s photographs whisper something different. They show me that caution, passivity, the mundane and the everyday play a very large part in war and revolution. My first inklings of this came with making work prints of his negatives. These revealed details that had not been visible on the proof sheets. I noticed the caution of his framing. I also started to see into the crowds, and instead of heroic freedom fighters I found ordinary people wandering the streets, standing around, or peering out of apartment windows. By and large they are onlookers, not participants. Some even appear disinterested in the extra-ordinary events going on around them. In one photograph, a statue of a Red Army soldier is being hammered to pieces. While the noise must have been deafening, a man and a woman chat away amicably in the background. In another shot, a man pushes his bicycle across a bridge as two Soviet tanks rush by. Perhaps he was more concerned about being able to eat dinner that night, than the presence of the tanks. John MacCormac, writing for the New York Times about the uprising, called such scenes 'a touch of unreality', indicative of the extent to which professional images appearing in the media shape our sense of the reality of war (Gadney 1986, 58).

While my father took two or three photographs of men engaged in gestures that could be interpreted as heroic, what strikes me about his work is its lack of a constructed emotional appeal. Indeed, the physical distance of his framing is paralleled by an emotional distance in his gaze. ${ }^{4}$ His photographs appear cool, almost matter-of-fact. ${ }^{5}$ This is also true of his portraits of the dead.

\footnotetext{
${ }^{4}$ For me personally, there is a tension between this seemingly disinterested gaze, and my expectations about the emotions my father must have been feeling watching his capital destroyed and his countrymen dying.

${ }^{5}$ Interestingly, in the interviews I conducted with my father, he spoke very matter-of-factly about what happened in his pictures: 'You see this? Well, this happened, and then that', was his typical style of explanation. While he used the term 'freedom-fighter,' he very rarely used words such as 'hero' not to mention 'bravery' or 'tragedy.' His personality or his personal interpretation of the event could account for this. Nevertheless, it does not detract from what is going on in many of his photographs.
} 
In contrast to his street scenes, my father tended to photograph the dead from close range. In one picture of a Soviet soldier, I can see the insides of his leg-run over by a tankmashed and puffed up at the same time. In another photograph it is as if I can see into the dead man's skull. Another photograph frames an AVO corpse. The head is so mutilated as to be barely recognisable; cigarette butts are scattered all over the torso, mixed with dry blood and dirt. These are all enemy bodies. But whether enemies or loyal citizens, my father's photographs of the dead do not sensationalise, and in their coolness, their matterof-factness, they resonate strongly with Barthes’s argument that the amateur photograph stands closest to the noeme of photography: 'that-has-been' $(1980,76)$. They lie close to the underbelly of history. If we can filter though our distinctions of enemy/non-enemy, we are left with a compelling indication of what happens to bodies in wars. Of the logic of war, vis-à-vis the body.

And always, on the edges of the picture, is the presence of the crowd. What feelings and thoughts flooded the minds of those who gathered to gaze at the dead, I am not sure, but my father's photographs tell me that they wanted to look [see figure 4]. A dozen pairs

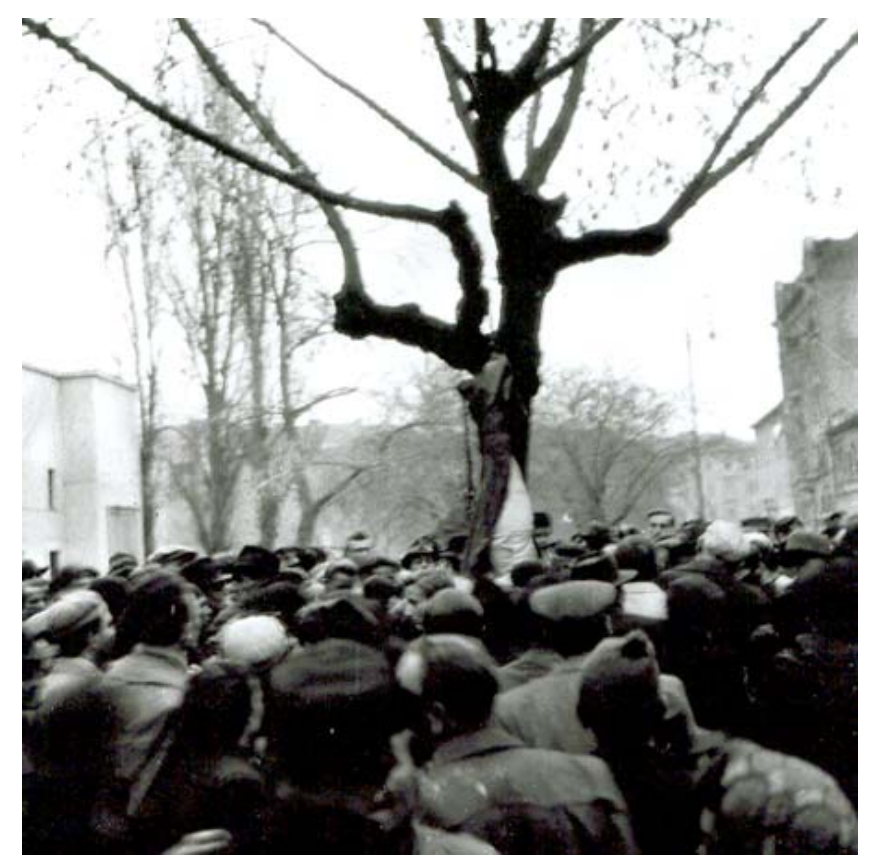

Figure 4: Photograph of a lynching at Republic Square, by Hajdú László, Budapest, 1956. 
of feet circle the dead body of an AVO, confronting its disfigurement, its smell. A man's shoulder is caught in the camera's parallax error as he takes in a scene of the black and twisted foot of a boy lying under an exploded vehicle. In the aftermath of the battle at Republic Square, crowds of bystanders strain for a view over the people in front of them. Clearly others are as interested in looking at death as I am.

The repetition of this motif of the crowd that has gathered to look, and the intense compulsion for visuality, is of particular interest to me as an artist who works with photography. It is significant that my father chose not to take up a gun, but to wander the streets specifically to see and to record. My relationship with his photographs duplicates this desire for knowledge through the visual. Most of the images in the individual panels in 1956: desire and the unknowable are massive enlargements of tiny sections of my father's negatives. In deciding the arrangements of these panels, I worked with a photocopier over the course of three or four months, repeatedly enlarging different sections of the work prints in different scales. The final panels were created first by printing sections of his original images, and then re-photographing smaller areas of these sections in order to create final work negatives. The prints that form the panels are thus $5^{\text {th }}$ generation croppings and enlargements of my father's original pictures - the final product of a compounded, compulsive homing-in.

The printed image excites a double desire in history: on the one hand, for the careful sifting and assembling of detailed and objective records; and, on the other, for the restoration of history as 'lived reality’ (Tagg 1995, 290). Looking at my father's photographs always prompts the question: 'What was it like- to be there, to experience that?' But the sheets of silver-gelatin before me yield little. I ask my father the same question, and he answers in a few terse words that fail to communicate the depth and intensity I desire.

My desire for a 'lived reality,' for an experiential history, prompted me to visit Budapest with my father in 2000, in order for us to retrace his steps. While it was impossible to go 
back in time, I could at least go back in space, and walk the same streets.

I found myself becoming obsessed with the minutia of noting exact addresses for buildings and becoming concerned with the exact position from which he took the pictures. I wanted to 'see' the photographs in the same way, so as to 'see' history in the same way. I remember the first time I stood in the precise location he had stood in fortyfour years ago. Holding the print (my overriding reality of Budapest, which I had gotten to know so intimately in the darkroom) in my hands-comparing it to the scene which now stood before me, I was overwhelmed by a feeling that the past was about to come breaking through the veneer of the present. It was this 'visual' experience that partly prompted me to present this work in a grid. The spaces between each image function like a mesh, through which the picture seems to want to melt and re-form itself before the viewer-a visual experience of the work that was particularly strong in the exhibition of this work in Between Ranke and the sublime.

At night in Budapest, I used to look over my father's photographs and write out notes about the day's findings. I wondered what 'newsreel images' might be running through my father's head, what he must be dreaming of, and longed for that experience to somehow be implanted into my own mind. But as he slept peacefully beside me I realised that his memories could never be mine. There was an unbridgeable gulf between us, because my experience of walking those streets in search of those pictures was inevitably different to his.

My hope that I could know what it was like to be in the historical event, by knowing his pictures as accurately as possible, failed. It was then that I came to understand the inadequacy of the Rankean will to access the truth of history through the document. For the past is ultimately unknowable, irretrievable through any medium. It has slipped by in the instant of the shutter. The sense of loss, the often inarticulate recognition that we can never return, is the 'lingering laceration' produced by the photograph (Shawcross 1997, 109). I suspect that this is what compels us to keep looking at photographs. And in my case, the experience of looking at those particular photographs was layered with the 
inarticulate condition of diaspora experience - that that past, my past, which is not my past, cannot be returned to, cannot ever be claimed fully.

I came to accept that no matter how intensely and methodically I worked with my father's photographs, the events of 1956 would remain like Hayden White's historical sublime (1986): ultimately incomprehensible: formless, irregular, absurd, grotesque; marked by disruption, dislocation and discontinuity; lacking a centre, inherently uncertain and inherently meaningless.

The traditional narrative is unable to express such a conception of the past, because requirements such as plot and narrative closure snuff out the sublime. Instead, new literary techniques such as splitting and fragmentation, and the avoidance of 'narrative omniscience over events’ become necessary. (Burgoyne 1996, 114-15) This is particularly true post-Holocaust, because of the impasse in imagination and explanation we are brought to by this event. Thus, 'anti-narrative non-histories' offer the 'only prospect for adequate representations of the kind of "unnatural' events"-including the Holocaust — that mark our era and distinguish it absolutely from all the "history" that comes before it' (White 1996, 32).

My gradual acceptance of such theoretical issues contributed to resolving many of the formal decisions that were part of the creation of this work. My father's images are fractured as they 'pass through' the grid, but the individual pieces are arranged so as to stimulate the human urge for continuity and unity. Depending on viewing distance, at first glance we may be deceived into seeing a complete picture. However, we soon realise that the pieces in each section do not come from one image that has been split up and spread out, but from separate images. A tension emerges between our recognition of the splintered fragments, and our now self-conscious desire to join the picture up into a comprehensible whole [see figure 5]. 

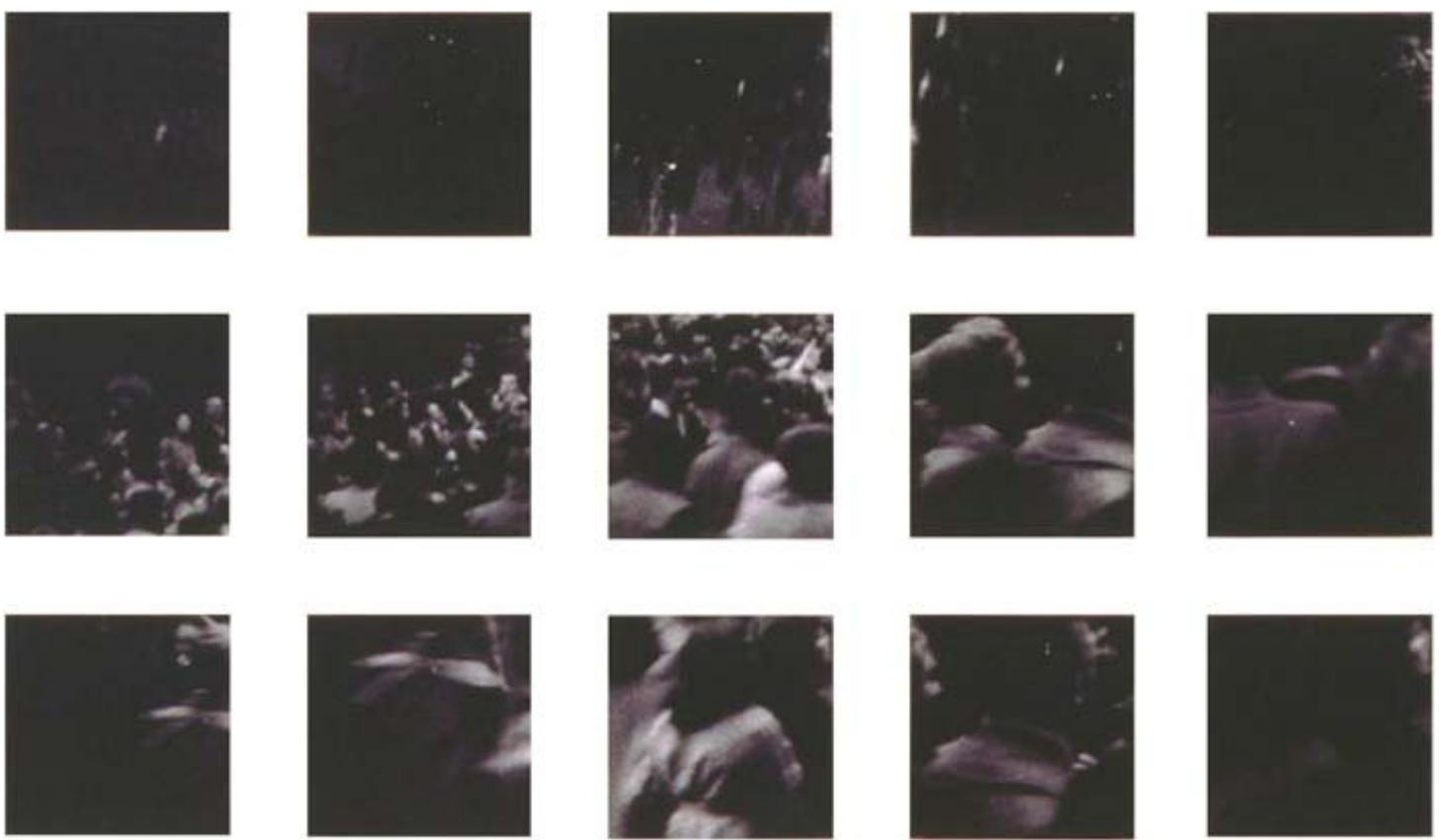

Figure 5: detail from 1956: desire and the unknowable, by Sue Hajdú 2001.

Such tension is expressive of our post-modern relationship with history and the narrative. For while the contemporary world is clearly different to the modernist one, it is still suffused with modernist residue - the comfortable, familiar concepts in which we still wish to believe but which are no longer adequate. We long for wholeness, we long for explainability. Our minds know that this can never be the case, but our hearts persist in their longing.

The tension produced between the grid of 1956: desire and the unknowable and the images themselves, parallels our oscillation. The grid functions similarly to the traditional narrative in that it 'excludes the irrational, the non-causal, perceptual links that lie outside of what might be called the "agreeable.” The grid provides a void-as-space in which form can exist in a way that is agreeable, measurable, common-sense-truth' (Loveday 1999). Yet it strains to perform this function against the irrationalities, distortions and mysteries within the images. The prints are dark, often obscure. Traditional respect for tonal scale and shadow detail — the hallmarks of the modernist 'good print' — have been abandoned. The question 'what are they looking at?' cannot be answered. It lies obscured in overly 
enlarged grains of silver and black lacunas that deny visuality. The work lacks a clear centre of interest. Distortions in scale and perspective disorient the viewer, as do the repetitions. This kind of story-telling becomes 'not an explanation, but an obsessive recounting, not a consistent description but a series of impressions, polarising coherence and cohesion’ (Clive 1999, 225-27).

We are left with a relationship between photography and the historical event that is radically different to that of a documentary practice. My decision to re-photograph prints of my father's images, rather than working directly from his negatives, produces a grainy result which is clearly a copy, thereby acknowledging my essentially vicarious relationship to the past. This expresses the double-index of his/my their/our desire to know the historical through the act of looking. 1956: desire and the unknowable thus becomes my vision of 1956, rather than my father's [see figure 6].
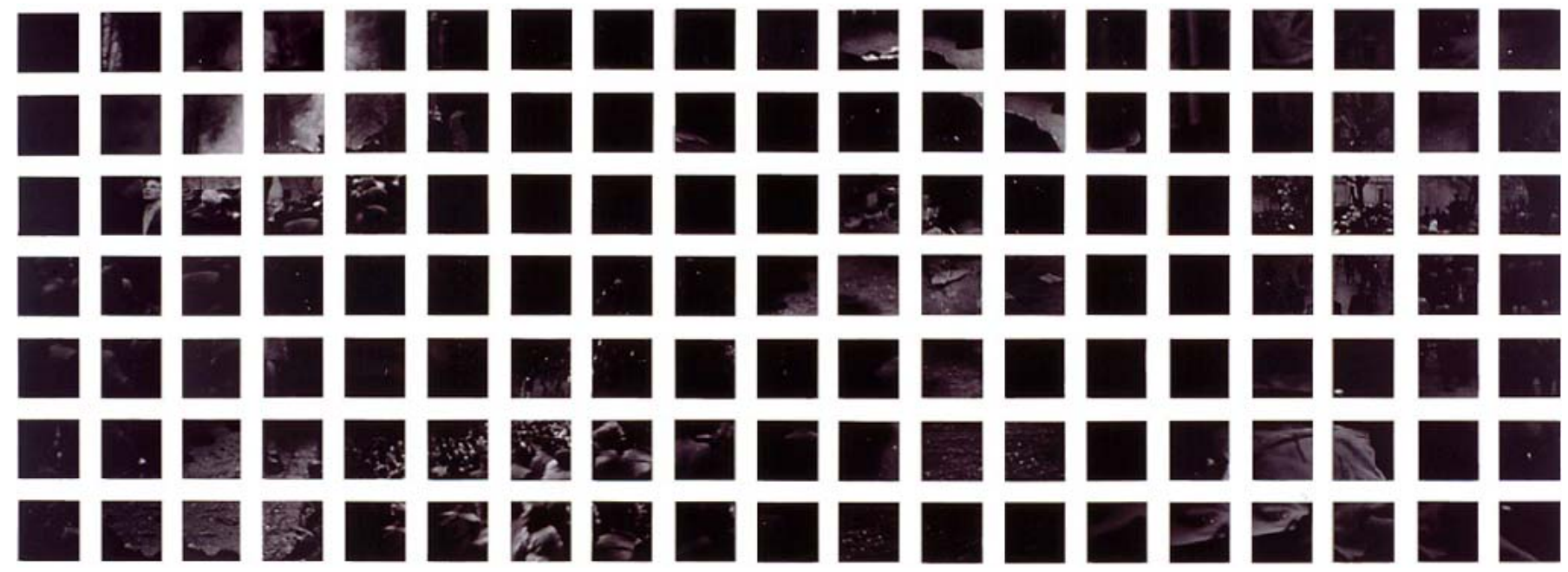

Figure 6: 1956: desire and the unknowable, by Sue Hajdú, 2001.

Selenium-toned silver gelatin prints, mounted on PVC.

Dimensions: $125 \mathrm{~cm}$ x $81 \mathrm{~cm}$ (individual panels: 9 x 9cm).

The question remains as to what I gained from my research trip back to Budapest with my father. The lived reality of the Hungarian Revolution proved inaccessible to me. However, I was able to stand in almost all of the locations in which he took his 
photographs and I was able to trace the route that he once walked, from negative to negative, as he photographed. And then there were the hours spent questioning, listening, recording, remembering. I feel comfortable saying that my knowledge of his pictures is now as intimate as his, albeit in a different way.

This process has resulted in a transferal, but not only of facts and stories, which almost any stranger can gain. It is the transferal to the body-the result of all that walking side by side-that interests me more, because some of the knowledge that exists in his body has now been passed on to mine. I am his daughter. So this is a process of generational transferal. A diasporic inheritance of both the intellect and the body. Budapest does indeed now resonate with past humanity, with spirit of place. I can no longer look at those pavements and buildings innocently.

This bodily transferal of historical knowledge relates closely to my discussion about looking in the second section of this paper. I interpret the desirous looking of the crowd as the human compulsion to 'take in', in an attempt to come to terms with both the biggest mysteries of life and the enormity of $20^{\text {th }}$ century events. Writing about the Vietnam War in Dispatches, Michael Herr relates a scene in which a soldier, hit by a mortar round, has propped himself up against a tree:

making himself look at the incredible thing that had just happened to his leg, screwed around about once at some point below his knee like a goofy scarecrow. He looked away and then back again, looking at it for a few seconds longer each time, then he settled in for about a minute, shaking his head and smiling, until his face became serious and he passed out. $(1978,33)$

I do not interpret looking at the body in this way as morbid or voyeuristic. To 'take in' death, to endeavour to know death in this way, is the same as the attempt to come to terms with the mystery of the human body in birth, or in the sexual act. It is here that I appreciate the coolness of my father's gaze the most. Because of the way he neither flinches at, nor sensationalises, nor moralises the scenes where crowds look at the dead, where they clearly want to look at the dead, I am able embrace this desire as a part of my humanness. 
Nevertheless, it must be a difficult task to look at scenes where one human has caused another such damage. Even amongst those who had good reason to hate the AVO, there must have been some who looked away. The complexity involved in such acts of looking is discussed by Inga Clendinnen in Reading the Holocaust. She quotes Charlotte Delbo, writing about a woman being dragged to the gas chamber: 'Try to look. Just try and see' (1998, 63). Why? Because to look at the dead on Budapest's streets or in the concentration camps, is not only to take in death, but also to take in history- to know, in the most unmediated manner, what man has done to man. There is a moral imperative in this act. For to make oneself witness, to retain that information in one's body and to hopefully one day pass it on, was to resist the ultimate horror of the camps: the deliberate destruction of all records of the destruction.

Visual representation of the body in war is a similarly fraught issue. While my father's photographs are discreet and respectful, they reveal rather than obscure physical mutilation. We must have access to images such as these, to an alternative to press photography of war. Because governments do send bodies into war and annihilate them, whilst denying this reality in representation. Meanwhile the glorification of heroism continues.

It is better to know.

The act of staying attentive to the past counts. Clendinnen places that duty of attention squarely on our shoulders, and not on those of the survivors of painful historical events. Luckily for all of us, some did survive, and are willing to tell. The rest of us have the moral imperative to ask, to listen and to look. And I agree with Clendinnen's view that these acts should be as disciplined and as critical as possible $(1998,206)$ We should strive to know as accurately as possible, as much as possible, even while admitting that there will be inevitable absences and lacunas. It is this tension inherent in a post-modern historiographical position that I have intended to ride in my work. 
As such knowledge is transferred to the next-generation body, the voice of the diaspora child becomes able to speak. If my father were of a different temperament, or had different abilities, perhaps he would have compiled his photographs and published them. That task has now become mine. 1956: desire and the unknowable was my first attempt at addressing his oeuvre, and it was a very personal statement. In the course of researching and producing this piece I realized that our cross-generational project had not yet reached its full potential. So the oral history interviews have continued, as has my research. Our collaboration across time will result in the publication of a book, entitled My Father's Photographs. My father's vision will be retained through each of his photographs, presented in sequence. Beside them, my words. Another voice, and a narrative that is accepting of the fracturing, the silences and omissions, the desire to comprehend sitting against the incomprehensibility. A voice that places that past in the now. Many of the themes raised in this paper will appear, as will references to our interviews, our relationship to each other through the event, my relationship with his images and with that history, his motivations, my desire to know him as he was then, my position as diaspora - precisely because of that event.

History's dead are gone.

What remains of their actions once they are gone?

As Scott McQuire writes, 'The permanence or impermanence of any memory always depends on others, on the extent to which the living are prepared to assume responsibility for the lives of the dead' $(1998,164)$.

The dead.

Not just my father, one day; but all of them. 


\section{Reference List}

Barthes, R. 1980, Camera Lucida: Reflections on Photography, trans. R. Howard, Fontana, London.

Brothers, C. 1997, War and Photography: A Cultural History, Routledge, London and New York.

Burgoyne, R. 1996, 'Modernism and the Narrative of Nation in JFK', in The Persistence of History: Cinema, Television and the Modern Event, ed. V. Sobchack, Routledge, New York and London, 113-125.

Clendinnen, I. 1998, Reading the Holocaust, Text Publishing, Melbourne.

Clive, S. 1999, The Spoken Image: Photography and Language, Reaktion Books, London.

Crime Scene: Scientific Investigation Bureau Archives: 1945-1960, [Exhibition] 13/11/1999 - 2/10/2000, Justice and Police Museum, Sydney.

Gadney, R. 1986, Cry Hungary: Uprising 1956, Weidenfeld and Nicolson, London.

Gibson R. 1999, Crime Scene: Scientific Investigation Bureau Archives: 1945-1960 [Catalogue], Justice and Police Museum, Sydney.

Herr, M. 1978, Dispatches, Picador, London.

Loveday, T. 1999, Catalogue essay in Material Matters, ed. J. Rath, UTS Gallery, Sydney.

McDonald, A. 1988, 'Girl Dancer at Rigo Festival', Photofile, South Pacific, vol. 6, no. 1, 60-63.

McQuire, S. 1998, Visions of Modernity: Representation, Memory, Time and Space in the Age of the Camera, Sage, London.

Shawcross, N. M .1997, Roland Barthes on Photography : The Critical Tradition in Perspective, University Press of Florida, Miami.

Sontag, S. 1977, On Photography, Penguin, New York.

Tagg, J. 1995, 'The Pencil of History', in Fugitive Images: From Photography to Video, ed P. Petro, Indiana University Press, Bloomington \& Indianapolis, pp. 285-303.

White, H. 1996, 'The Modernist Event', in The Persistence of History: Cinema, Television and the Modern Event, ed. V. Sobchack, Routledge, New York and London, 17-38. 